\title{
Responsible self-medication: review of the process of pharmaceutical attendance
}

\author{
Dayani Galato $^{1,2, *}$, Luciana de Mattos Galafassi ${ }^{1}$, Graziela Modolon Alano ${ }^{1,2}$, \\ Silvana Cristina Trauthman ${ }^{1,2}$
}

\begin{abstract}
Specialization in Clinical Pharmacy, University of South Santa Catarina, ${ }^{2}$ Research Group on Pharmaceutical Care and Studies on Medication Use (NAFEUM), Pharmacy Undergraduate Program, University of South Santa Catarina.
\end{abstract}

\begin{abstract}
This article presents a review, based on a qualitative study, of pharmaceutical orientation in the management of minor illness. Action research methodology was used by a group of faculty members responsible for the community pharmacy internship and by postgraduates in clinical pharmacy, to carry out the study with the objective to present a standard service for this kind of procedure. The interaction with the individual starts with a welcoming reception, at which point the pharmacist should be receptive and show empathy. Subsequently, data from the history of the patient are collected to obtain relevant information. Based on this information, the pharmacist must develop a line of clinical reasoning and make a decision, taking the context of the patient into account. After this analysis, the most appropriate intervention is performed. This intervention could indicate the need for referral to another health professional, the use of a non-pharmacological therapy or the provision of sound advice on medicines available without prescription. The next step is monitoring the patient in order to identify the effectiveness and safety of treatment. The standardization process of pharmaceutical attendance in the management of minor disorders contributes to the rational use of medicines.
\end{abstract}

Uniterms: Self-medication. Community pharmacy. Drugs/rational use. Pharmaceutical orientation. Responsible self-medication. Minor illness.

A reflexão apresentada neste artigo representa um estudo de abordagem qualitativa baseada na pesquisaação da prática do atendimento farmacêutico no manejo de transtornos menores, realizada pelo grupo de professores do Estágio em Farmácia Comunitária e por farmacêuticos pós-graduados em Farmácia Clínica, com o objetivo de realizar uma proposta de atendimento padrão para este tipo de procedimento. A interação com o indivíduo é iniciada pelo acolhimento, momento no qual o farmacêutico deve ser receptivo e empático. A seguir, se executa a coleta de dados sobre a história do paciente, para obtenção de informações relevantes. Com base nas informações, o farmacêutico deve desenvolver um raciocínio clínico e tomar uma decisão, levando em consideração o contexto do paciente. Após esta análise é realizada a intervenção mais adequada ou o conjunto dessas que podem ser: procurar outro profissional de saúde, utilizar uma terapia não-farmacológica ou auxiliar na escolha de um medicamento de venda livre. $\mathrm{O}$ próximo passo é o acompanhamento do paciente com vistas a identificar a efetividade e segurança do tratamento. A padronização do processo de atendimento farmacêutico no manejo de transtornos menores, contribui para o uso racional de medicamentos.

Unitermos: Automedicação. Farmácia comunitária. Medicamentos/uso racional. Orientação farmacêutica. Automedicação responsável. Transtornos menores.

\section{INTRODUCTION}

The World Health Organization (WHO, 1998) and

*Correspondence: D. Galato. Núcleo de Pesquisa em Atenção Farmacêutica e Estudos de Utilização de Medicamentos (NAFEUM) - Curso de Farmácia UNISUL, Av. José Acácio Moreira, 787, Bairro Dehon, 88704-900 - Tubarão, SC-Brasil. Email: dayani.galato@unisul.br the International Pharmaceutical Federation (FIP, 1999) define self-medication as a practice by which an individual selects and uses medicines to treat symptoms or minor health problems, recognized as such by themselves. When done correctly, self-medication can benefit the individual's health and is recognized by the WHO as part of self-care (WHO, 1998; WSMI, 2006a). 
Self-care is understood as what a person does by themselves to establish and maintain health, preventing and dealing with disease. This concept includes health, nutrition, lifestyle, socioeconomic and environmental factors, as well as self-medication (WHO, 1998; WSMI, 2006a). Lately, individuals have taken greater personal responsibility for their health and are seeking more information to make appropriate decisions about their treatment (FIP, 1999) either from reliable sources or from other questionable sources, such as websites (Barros, 2004).

In the treatment of minor illness, when problems are self-limited, self-care can be used. According to Winfield and Richards (1998), the criteria for considering health problems as a minor illness include having limited duration and being perceived as non-threatening to the patient.

In the international arena, there is a change in the treatment of these minor ailments through using self-care, encouraged by drug policies in countries around world. For government institutions, this can reduce costs while allowing health professionals to focus on more serious health problems (Volmer; Lilja; Hamilton, 2007). When this occurs, and when the management of these ailments is accomplished through drugs or medicinal plants, it becomes self-medication. In this case, pharmacist orientation is important to guarantee a responsible self-medication plan.

It is estimated that in the United States, some 100 to 150 million general practitioner consultations a year are related to conditions that could be self-treated. Whittington et al., (2001) conducted a study in which patients with minor disorders who sought a general practitioner were sent to pharmacists in registered community pharmacies. The results indicated that these pharmacists were able to successfully resolve a series of minor disorders, through a specifically defined form, resulting in a small number of patients having to return to the doctor.

In recent decades, the pharmacist's role has been changing, being not only as drug dispenser, but acting as part of a multidisciplinary team involved in health care (WHO, 1998; Petty, 2003). It is important to emphasize the accessibility of consumers to the pharmacists, those working in either the public sector or in private pharmacies. Confirming such responsibility, Loyola Filho, et al, (2002) found significant association between pharmacist consultation and the use of non-prescribed drugs in Bambuí, Minas Gerais.

Each year, millions of new products are launched in the drug market as over-the-counter (OTC) medicines, and community pharmacists are in an excellent position to provide correct information on the use of these drugs (Blenkinsopp, Paxton, 2005; Covington, 2006). Even though a prescription for the sale of OTCs is not required, they can be harmful, creating risks to patients when used in incorrectly. It is noteworthy that in Brazil, 35\% of medicines are marketed through self-medication (Aquino, 2008).

While self-medication can produce good results and be a convenient practice for the patient (WSMI, 2006a; WSMI, 2006b; Covington, 2006), it can also cause serious health risks such as bacterial resistance, dependence, digestive bleeding, hypersensitivity reactions, drug withdrawal symptoms, as well as increase the risk of neoplasia. In addition to these risks, it should be emphasized that the momentary relief of symptoms may actually mask the underlying disease (Vilarino et al., 1998; Aquino, 2008).

The indiscriminate use of medicines can also increase the chances of intoxication, according to the National System of Toxic-Pharmacological Information (Sistema Nacional de Informações Tóxico-Farmacológicas - SINI$T O X)$; medicines are the second-most frequent causative agents of intoxication in humans. They are responsible for $26 \%$ of intoxication recorded in the country in 2005, where 590 cases were a result of self-medication (Bochner, 2005).

In a self-care context when there is need for medicines, the clinical pharmacist has a key role in assisting to identify the best intervention. This may include referral to another health professional, suggesting a different non-pharmacological therapy, helping to choose an OTC medicine that is safe and effective, and ensuring that it is used correctly (WHO, 1998, Wazaify et al., 2005; Covington, 2006).

Therefore, responsible self-medication promotes the rational use of medicines. According to the World Health Organization, the rational use of medicines is regarded as a situation in which the patient receives the appropriate medicine for their clinical need, at a correct dosage, for an appropriate period of time, and at a lower cost to themselves and the community (WHO, 2002).

However, to ensure responsible self-medication, it is necessary for pharmaceutical establishments to have a standardized sequence of actions for a particular patient care procedure in order to manage care adequately. An initiative in this direction was taken by the European Union which has developed protocols for minor disorders that help in the interview and decision making stages (Cordero et al., 2001).

The objective of this article is to examine the pharmaceutical attendance process that requires guidance in managing minor disorders recognized as such by patients or their caregivers at pharmaceutical establishments.

\section{METHODS}

The review presented in this article follows a qualitative approach based upon action research methodology 
(Minayo, 2004) of the pharmaceutical care practice in the management of minor disorders, and was performed by a group of faculty members responsible for the community pharmacy internship, and by postgraduates in clinical pharmacy.

This review arose from the need to establish a care standard for the process of responsible self-medication at the University Pharmacy School.

The results presented in this paper are represented in a flowchart showing the process of pharmaceutical attendance in the management of minor disorders. For each stage, the necessary guidelines for decision making are discussed, based on the literature whenever possible.

It is important to note that the authors of this article adopted the word user to represent the person asking the pharmacy to manage a health problem and the word patient to represent individuals having a health problem. This distinction is important because user and patient have different connotations.

\section{RESULTS AND DISCUSSION}

When the clinical pharmacist is available to assist the process of responsible self-medication, it is important to emphasize that interventions should only occur in situations when a minor disorder is identified.

The term model of care is used to present various steps that should constitute the process of responsible self-medication. It is at the discretion of the professional to determine the sequence of steps needed using a style and manner of questioning consistent with the situation that that fosters spontaneous consultation. This allows the clinical pharmacist to develop their own method of questioning for data collection in which he can encourage conversation with the patient. Blenkinsopp and Paxton (2005) also reinforce the importance of allowing flexibility and adaptation of the model to the professional's individual characteristics. It must be emphasized that this should be performed only by pharmacists, as it is their exclusive responsibility while on duty in a pharmacy.

In the process of self-medication in pharmaceutical care, it is important to identify the pharmacy user, whether they represent another customer about whom they are unable to provide more detailed information, or if they are responsible for the patient (caregiver), or they are themselves the patient.

\section{Welcoming reception: the beginning of interaction}

The interaction can be initiated by either the pharmacist or the user. In the welcome reception, communication is essential in order to develop a therapeutic relationship (Berardi et al., 2000; Cipolle, Strand, Morley, 2004). In this context, the pharmacist should show empathy, convey confidence, and be receptive to create conditions conducive for conducting the interview and collecting patient data (as described by Galato et al., 2008).

If the pharmacist is not acquainted with the user, it is important to introduce themselves personally by saying, "Hello, are you doing? I am the duty pharmacist here. How may I help you?" Similarly, the user should be addressed by his or her name (Berger, 2005).

It is essential to identify the person with the complaint that led to pharmaceutical care being sought. This point is important because it will dictate how the entire service is rendered, as follows:

\section{Situation in which the user is the patient or caregiver}

\section{Data collection on the history of the patient}

In this situation, the pharmacist is able to explore the information needed to make a decision on the intervention. For this to occur, it is essential that the pharmacist has the appropriate communication skills to collect information, as well as knowledge of minor disorders and therapeutic alternatives. Without this ability and knowledge, it is impossible to collect data adequately and consequently responsible self-medication cannot occur. This requires the professional to be prepared through continuous study and professional development.

Initially, data should be collected on the patient's profile, such as age, gender (usually obtained by visual observation), current diseases, medications, and other products in use, as well as medicinal and food supplements, or herbal teas. It is also important to learn if the patient has any allergies as well as gather information on family disease history (Swartz, 1992).

With regard to the initial complaint that led to seeking the pharmacy establishment, it is important to ascertain information such as: when did it start, how often does this occur, with what severity, what has already been done to address it, what was the result of previous treatment, is this a recurrent problem, and how was the problem resolved in that situation? During this phase it is important that the pharmacist focuses on both the patient's verbal and nonverbal communication. Special attention should be given to the use of open questions, as exemplified above, in order to avoid inducing implied responses. The use negative words should be avoided, especially by questioning "why", since it could suggest that the pharmacist would prefer responses confirming the negative, or disapprove 
of the focus of the question (Swartz, 1992). Questioning skills should be trained, so as not to ask for unnecessary information or that the patient has already provided.

When the data collection generates user mistrust or discomfort, the pharmacist must explain the importance of the information related to the symptoms and how it contributes to the best selection of treatment alternatives, and that any information collected is strictly confidential (Conselho Federal de Farmácia, 2004).

Besides the previously emphasized communication skills, it is essential to have accurate knowledge of minor disorders and alternative therapies in order to collect information adequately; deficiencies in communication skills or lack of knowledge make the process of data collection inefficient, impairing the professional's ability to develop responsible self-medication.

Pharmacists can perform their function properly when they are fully capable of distinguishing between minor and major disorders (Blenkinsopp, Paxton, 2005). This requires careful observation and adequate questioning to identify the symptoms reported by patients, which may have a potentially serious cause. In this case, the patient should be referred to a health specialist (Winfield, Richards, 1998).

\section{Data compilation and pharmaceutical intervention}

Once the information is collected, the pharmacist should then be able to develop a clinical analysis regarding the patient's ailment. If in doubt, further inquiry should be made before reaching a decision. However, in most situations, the pharmacist is constantly assessing their plan of action as the inquiry proceeds.

After examining the patient's condition, the pharmacist may determine that it is not a minor disorder, or that it is a special situation. In this case, the patient or caregiver should be advised to seek appropriate professional help, usually from a physician.

In the previous situation, pharmaceutical intervention can target the temporarily relief of symptoms, or prevent further complications. Examples of special situations include the elderly, children, pregnant women, patients with chronic diseases, poly-medicated individuals, and recently hospitalized patients. The physician should always be consulted, either in person (Berardi et al., 2000) or at least by being notified as soon as possible about the intervention performed. However, it is important to note that some studies (Cascaes et al., 2008; Pereira et al., 2007; Osorio de Castro; Paumgartten; Silver, 2004) have shown that, even in special cases, self-medication is a common practice that needs to be streamlined.

However, there are often cases in which the subjects have received prior advice from their doctor to self-me- dicate in certain situations; this is common, especially in the areas of pediatrics and obstetrics. In these situations, it is the pharmacist's responsibility to assess the patient's complaint and provide the medication (previously selected by the prescriber) only when they are satisfied that the signs and symptoms are characteristic of minor disorders.

The guidelines for monitoring should be strengthened, emphasizing that patients should be referred to a doctor in cases of persistent or worsening symptoms. Winfield and Richards (1998) explain that an initial doctor's consultation is required for correct diagnosis and proper treatment, as well as subsequent monitoring of the individual. Accordingly, the doctor recommends the same treatment to control similar symptoms identified by the patient, such as an allergy, for example.

When a minor disorder occurs in a given patient not classified as a special case, such as those mentioned earlier, the use of an OTC medicine or other non-pharmacological therapeutic approach can be suggested. The method adopted should be explained to the patient by referring to the main complaint and presenting the possibilities of management.

To address the main complaint, the symptoms described by patients that help identify the problem as a minor disorder should be reviewed. This would provide the patient with the opportunity to clarify the signs and symptoms being reported. At the same time, it allows pharmacists to better understand the data they have collected, as well as patients to understand their current health status and needs for treatment. In other words, those symptoms that can be alleviated are identified, although the disorder may not immediately be resolved, a typical characteristic of minor health problems. Subsequently, treatment possibilities are presented to the patient, who is also given an explanation on the function of each procedure in order to decide which drugs will be selected. In situations where the pharmacist has just a single treatment option available at the pharmacy, then the professional should adopt the most appropriate treatment for that situation by explaining which drugs are available. Another option is to suggest that the patient wait for the pharmacy to purchase a different product that could also be used (a common practice that has been facilitated by the present rapid medicine distribution system).

There are also situations in which patients or caregivers intend to use an alternative therapy which they have used previously, or intend to purchase a particular product for the management of their symptoms. In these situations, the pharmacist must assess the patients' selection to see whether it is appropriate. If it is not, the pharmacist should present and explain the different options available. 
In situations where an alternative therapy is selected (in this case, always represented by OTC medicines), the pharmacist should:

- $\quad$ Draw up a plan to be followed by the patient, outlining the objectives to be achieved (Cipolle; Strand; Morley, 2006).

- $\quad$ Provide information on dosage, the most common adverse reactions, and expected effect and interactions, while paying attention not to overburden the user with too much information.

- Highlight or write down the most important guidelines for the patient to remember; in this case, pictograms can also be used (Galato et al., 2006).

- Make sure that the patient understands the instructions, related to both the use and the expected effect. It is always important to remember that the pharmacological management adopted may not be the only one available. As previously noted, minor health disorders are self-limited, therefore they respond well to non-pharmacological management which is usually upon adoption of simple care, or even a change in lifestyle.

The pharmacist must inform the patient how the minor disorder is expected to evolve, and if it does not improve, they should reinforce the need to return to the pharmacy or refer the patient to a doctor for professional care. Finally, the patient must understand the need for pharmaceutical intervention monitoring, when appropriate.

\section{Intervention monitoring and evaluation of results}

In intervention monitoring, it is vital that the patient understands the expected evolution of the minor disorder to ensure that selected treatment is effective. For this to occur, the pharmacist should explain to the patient, for example, "your flu will get better in a week; if it does not, consult your doctor. If new symptoms arise, you can check back with me as I have already seen you (or you may consult another pharmacist) to re-evaluate the situation."

Moreover, the patient must be aware of the warning signs and symptoms that may appear. In case of worsening, they must be instructed to consult a doctor. The patient should be informed of how this may manifest, for example: "in case of fever, an increase in temperature can indicate a worsening condition".

Intervention monitoring should be encouraged in all situations, requiring the person to return to the pharmacy after a predetermined time to make sure that the selected treatment was appropriate, and whether or not a new assessment is necessary. If the treatment was found to be ineffective or unsafe, the causes should be evaluated by reexamining the patient to determine if the case is really a minor disorder, and if the patient should consult another health professional.

In case of any adverse reaction, the pharmacist must inform the National Sanitary Surveillance Agency (Agencia Nacional de Vigilância Sanitária - ANVISA) through the appropriate electronic form (ANVISA, 2008). Both the patient's data and the pharmacist's decision should be recorded on a form and stored in the pharmacy. The result(s) obtained can also be recorded, when possible, in the event the patient returns to the pharmacy. This allows the pharmacist to constantly evaluate the quality of their interventions related to responsible self-medication. This contact does not necessarily need to be done in person, since the user and/or caregiver can be reached by telephone.

The practice of recording the pharmacist's actions is similar to that in the process of pharmaceutical care, where the pharmacist takes joint responsibility with the patient for the pharmacotherapy in order to prevent, identify and solve problems related to medications by assessing their necessity, effectiveness and safety (Hepler, Strand, 1990; Cipolle, Strand, Morley, 2004). Therefore, it must be emphasized that self-medication can take place during the process of pharmaceutical care, or constitute entry of new patients to this service.

\section{Situation in which the user is neither the patient nor the caregiver}

This is a very complex situation, though very common in pharmaceutical establishments, because in most cases it is not possible to collect data on the patient's history, while often the user arrives at the pharmacy with the task of buying a particular product. In this case, information should be analyzed as far as possible and provide only products that are exempt from prescription and that have no possibility of conflicting with the profile of the patient identified in the situation.

In case of doubt or lack of important information, the pharmacist should try to contact the patient by telephone, for example, to clarify points deemed critical to health care delivery.

If doubts cannot be resolved or if there are identified incompatibilities, the product should not be dispensed.

Regardless of the position taken in this situation, the pharmacist must provide information (advice) on the symptoms presented by patients, even when the service was completed without delivery of a product, so that the user or the person who went to purchase the product, understands the reasons why the pharmacist has made this decision. Furthermore, the professional must always provide information for further contact. 


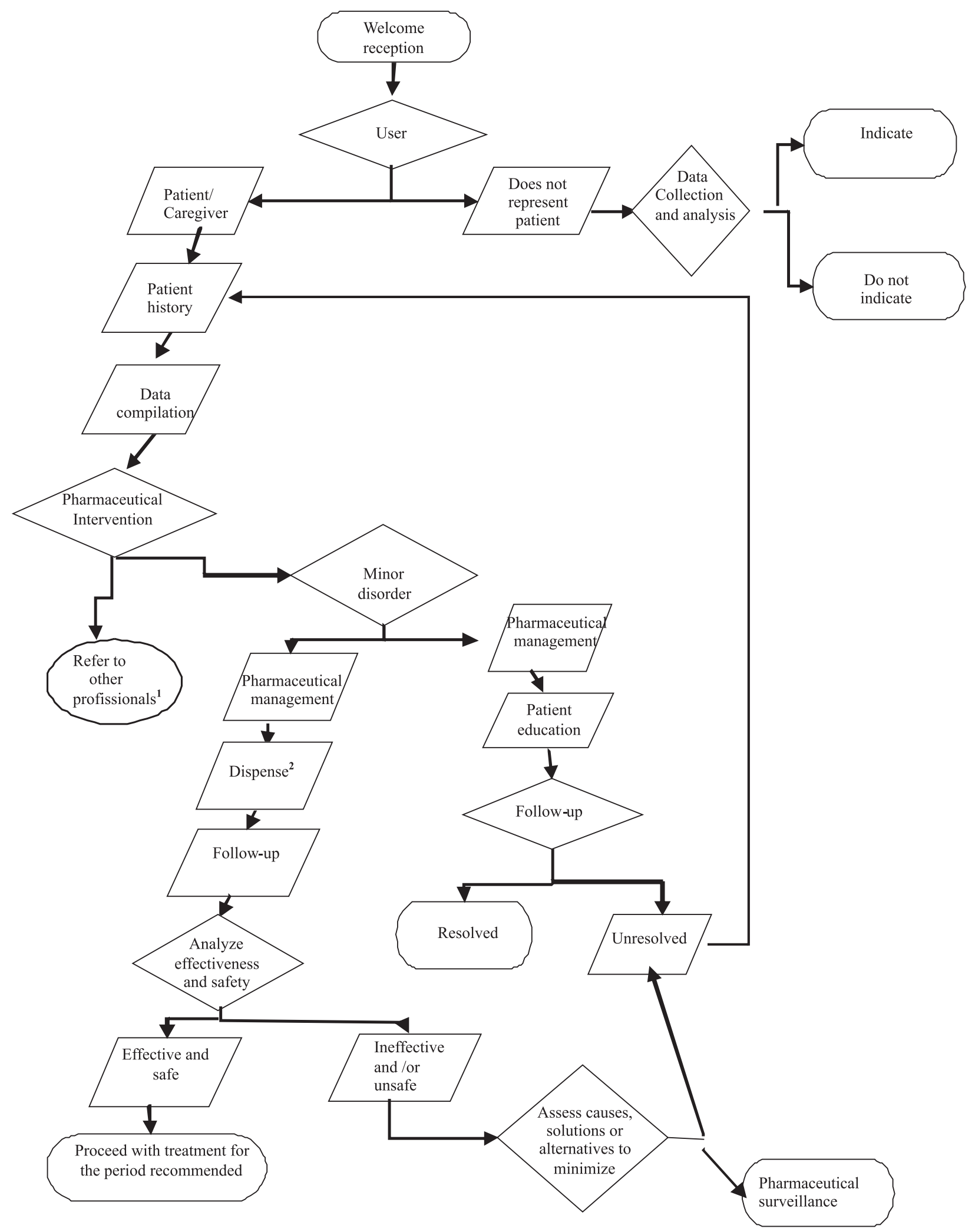

1. Elderly, children, chronically ill, poly-medicated, and recently hospitalized.

2. To dispense, providing instruction on indication, expected effect, duration of treatment (and other information such as interactions and adverse effects must be presented when appropriate).

FIGURE 1 - Process of attendance in the management of minor illness. 


\section{Responsible self-medication and pharmaceutical commerce}

The pharmacy is a facility that combines the production and use of medicines. In recent years, the community pharmacy has been regarded less as a national health service and more as a commercial establishment (Barros, 1997). Thus, the influence of commerce through the advertisement of medicines (Barros, 2004), subsidy policies, and commission on sales can be an obstacle to the promotion of rational use of medicines.

However, responsible self-medication, when put into practice, requires the pharmacy to have a health establishment profile. In this context, the pharmacist values the patients care while minimizing conflict with commercial interests. It is therefore important to emphasize that the greatest return for the pharmaceutical establishment should be the sale of products related to prescribed medicines, and the provision of services (such as measurement of blood pressure and injection administration). In addition, a pharmacy designed as a health establishment should comply with regulations, provide the physical infrastructure, services and above all, the appropriate professional skills and attitudes for those who work there (Galato, Angeloni, 2009).

It is important to note that self-medication cannot simply be denied and ignored by pharmacists. Criteria should be established to manage this in a responsible manner, as recommended by respected organizations such as the World Health Organization (WHO), the International Federation of Pharmaceutical Industry, and the World Self-Medication Industry (WSMI), as well as the Federal Council of Pharmacy (Conselho Federal de Farmácia, 2001).

\section{CONCLUSION}

The review presented in this article highlights the importance of standardizing patient care with minor disorders. In addition to pursuing the establishment of a model of care, it is necessary for clinical pharmacists to constantly engage in the process of self-evaluation and to seek improvement and new knowledge that can provide quality service. However, it should be emphasized that this model is not intended to advocate self-medication, but to provide a process of responsible self-medication in order to promote the rational use of medicines.

Furthermore, the ability to communicate effectively is essential to ensure service quality. In this sense, the internship performed during the education stage helps students develop this skill, which will be very useful in their professional career.
In addition to effective communication, the pharmacist should have knowledge about minor disorders and other health issues, as well as on medicines (either nonprescription drugs that can be adopted in a selfmedication regimen, or those for continuous use by patients). Moreover, knowledge of other strategies related to self-medication is of fundamental importance in the management of health problems; particularly since the medicalization of society cannot be ignored by health professionals (Barros, 2004).

The pharmacist should work in co-operation with the health team, performing the role of a professional with a focus on patient health and on using medicines as a tool. As part of this review, it is important to emphasize that quality care can only exist when a responsible partnership between the patient or caregiver and the pharmacist is in place. Therefore, pharmacists' role in society constitutes an important contribution to the rational use of medicines, particularly in situations characterized as self-medication.

\section{ACKNOWLEDGMENTS}

Special thanks go to professors Wellington Barros da Silva, Eugênio Zimmer Neves, Karina Saviatto de Carvalho and Ana Cristina Vieira for initial discussions regarding this issue and the proposals for systematizing the process of pharmaceutical care. Thanks also go to the trainees and Unisul Pharmacy students, as well as to the pharmacists of Farma \& Farma for the contributions made in the improvement workshops.

\section{REFERENCES}

AGÊNCIA NACIONAL DE VIGILÂNCIA SANITÁRIA. Farmacovigilância: farmácias notificadoras. Avaiable at: $<\mathrm{http}$ //www.anvisa.gov.br/farmacovigilancia/farmacias_ notificadoras.htm>. Accessed on: 04 jul. 2008.

AQUINO, D. S. Por que o uso racional de medicamentos deve ser uma prioridade? Ciênc. Saúde Coletiva, v.13, p.733$736,2008$.

BARROS, J. A. C. A atuação de balconistas de farmácia: ajudando a promover o uso racional de medicamentos? $J$. Bras. Med., v.73, n.2, p.120-127, 1997.

BARROS, J. A. C. Políticas farmacêuticas: o serviço dos interesses da saúde? Brasília: UNESCO, 2004. 270 p. 
BERARDI, R. R.; KROON, L. A.; MCDERMOTT, J. H.; NEWTON, G. D.; OSZKO, M. A.; POPOVICH, N. G.; REMINGTON, T. L.; ROLLINS, C. J.; SHIMP, L. A.; TIETZE, K. J. Handbook of nonprescription drugs: an interactive approach to self-care. 13.ed. Washington: Apha, 2000. $1190 \mathrm{p}$

BERGER, B. A. Communication skills for pharmacists: building relationships and improvise patient care. Washington: American Pharmaceutical Association, 2005. 212 p.

BLENKINSOPP, A.; PAXTON, P.; BLENKINSOPP, J. Symptoms in the pharmacy: a guide to the management of common illness. 5.ed. Oxford: Blackwell Science, 2005. $291 \mathrm{p}$.

BOCHNER, R. Casos registrados de intoxicação humana e envenenamento: uma análise. 2005. Avaiable at: $<$ http:// www.fiocruz.br/sinitox/2005/umaanalise2005.htm $>$. Accessed on: 21 jun. 2008.

CASCAES, E. A.; FALCHETTI, M. L.; GALATO, D. Perfil da automedicação em idosos participantes de grupos da terceira idade de uma cidade do sul do Brasil. Arq. Cat. Med., v.37, n.1, p.63-69, 2008.

CiPOLlE, R. J.; STRAND, L. M.; MORLEY, P. C. Pharmaceutical care practice: the clinician's guide. 2.ed. New York: McGraw-Hill, 2004. 394 p.

CONSELHO FEDERAL DE FARMÁCIA. Resolução n.417, de 29 de setembro de 2004. Aprova o código de ética da profissão farmacêutica. Diário Oficial da União, Brasília, nov. 2004. Seção1, p306-307.

CONSELHO FEDERAL DE FARMÁCIA. Resolução n.357, de 20 de abril de 2001. Aprova o regulamento técnico das boas práticas de farmácia. Diário Oficial da União, Brasília, apr. 2001. Avaiable at: <http://www.cff.org.br/userfiles/file/ resolucoes/357.pdf>. Accessed on: 03 fev. 2009.

COVINGTON, T. R. Nonprescription drug therapy: issues and opportunities. Am. J. Pharm. Ed., v.70, n.6, p.137-141, 2006.

FEDERACIÓN INTERNACIONAL DE FARMÁCIA. The World Self-medication Industry. Joint statement: Responsible Self-medication, 1999. Avaiable at: <http:// www.wsmi.org/pdf/fip.pdf.>. Accessed on: 15 may 2008.
CORDERO, L.; GIORGIO, F.; FERNÁNDEZ-LLIMÓS, F.; CADAVID, M. I.; GATO, A. LOZA, M. I. Protocolos para transtornos menores Del proyecto TESEMED: Estreñimiento. Pharm. Care Esp., v.3, p.155-174, 2001.

GALATO, D.; ALANO, G. M.; TRAUTHMAN, S. C.; VIEIRA, A. C. A dispensação de medicamentos: uma reflexão sobre o processo para prevenção, identificação e resolução de problemas relacionados à farmacoterapia. Rev. Bras. Ciênc. Farm., v.34, n.3, p.465-475, 2008.

GALATO, D.; ANGELONI, L. A farmácia como estabelecimento de saúde: a visão do usuário de medicamentos. Rev. Bras. Farm., v.90, n.1, p.14-18, 2009.

GALATO, F.; JUST, M. C.; GALATO, D.; SILVA, W. B. Desenvolvimento e validação de pictogramas para o uso correto de medicamentos: descrição de um estudo piloto. Acta Farm. Bonaer, v.25, n.1, p.131-138, 2006.

HEPLER, C. D.; STRAND, L. M. Opportunities and responsibilities in pharmaceutical care. Am. J. Hosp. Pharm., v.47, p.533-543, 1990.

LOYOLA FILHO, A. I.; UCHOA, E.; GUERRA, H. L.; FIRMO, J. O. A.; LIMA COSTA, M. F. Prevalência e fatores associados à automedicação: resultados do projeto Bambuí. Rev. Saúde Pública, v.36, n.1, p.55-62, 2002.

MINAYO, M. C. S. O desafio do conhecimento: pesquisa qualitativa em saúde. 8.ed. São Paulo: Hucitec, 2004. 269p.

ORGANIZACIÓN MUNDIAL DE LA SALUD. Promoción del uso racional de medicamentos: componentes centrales. Genebra: OMS, 2002. Avaiable at: <http://www.who.int/ medicinedocs/collect/edmweb/pdf/s4874s/s4874s.pdf $>$. Accessed on: 15 nov. 2007.

OSORIO DE CASTRO, C. G. S.; PAUMGARTTEN, F. J. R.; SILVER, L. D. O uso de medicamentos na gravidez. Ciênc. Saúde Colet., v.9, n.4, p.987-996, 2004.

PEREIRA, F. S. V. T.; BUCARETCHI, F.; STEPHAN, C.; CORDEIRO, R. Automedicação em crianças e adolescentes. J. Pediatr., v.83, n.5, p.453-458, 2007.

PETTY, D. Drugs and professional interactions: the modern day pharmacist. Heart, v.89, p.31-32, 2003.

SWARTZ, M. H. Semiologia: anamnese e exame físico. Rio de Janeiro: Guanabara Koogan, 1992. 511 p. 
VILARINO, F. J.; SOARES, C. I.;SILVEIRA, C. M.;RÖDEL,A. P. P.; BORTOLI, R.; LEMOS, R. R. Perfil da automedicação em município do sul do Brasil. Rev. Saúde Pública, v.32, n.1, p.43-49, 1998.

VOLMER, D.; LILJA, J.; HAMILTON, D. How well informed are pharmacy customers in Estonia about minor illnesses and over-the-counter medicines. Medicina (Kaunas), v.43, n.1, p.70-78, 2007.

WAZAIFY, M.; SHIELDS, E.; HUGHES, C. M.; MCELNAY, J. C. Societal perspectives on over-the-counter (OTC) medicines. Fam. Pract., v.22, n.2, p.170-176, 2005.

WINFIELD, A. J.; RICHARDS, R. M. E. Pharmaceutical practice. 2.ed. Hong Kong: Churchill Livingstone, 1998. 523 p.

WHITTINGTON, Z.; CANTRILL, J.; HASSELL, K.; BATES, F.; NOYCE, P. Community pharmacy management of minor conditions: the "at the chemist" scheme. Pharm J., v.266, p.425-428, 2001.
WORLD HEALTH ORGANIZATION. The role of the pharmacist in self-care and self-medication. Hangue: World Health Organization, 1998. 17p.

WORLD SELF-MEDICATON INDUSTRY. WSMI declaration on self-care and self medication, 2006a. Avaiable at: $<$ http://www.wsmi.org/pdf/boarddeclarationselfcare.pdf $>$. Accessed on: 28 jan. 2009.

WORLD SELF-MEDICATION INDUSTRY. Responsible selfcare and self-medication: a worldwide review of consumer surveys. Ferney-Voltare: WSMI, 2006b. 16 p. Avaiable at: $<$ http://www.wsmi.org/pdf/wsmibro3.pdf $>$. Accessed on: 28 jan. 2009.

Received for publication on $23^{\text {th }}$ October 2008. Accepted for publication on $18^{\text {th }}$ Febuary 2009. 
